\title{
Analysis of Genetic
}

\section{Variability of Austrian Pine}

(Pinus nigra Arnold) in

Serbia Using Protein Markers

\begin{abstract}
Aleksandar Lučić
Institute of Forestry,

Kneza Viseslava 3

11000 Belgrade

Serbia

\section{Radovan Nevenić}

Institute of Forestry,

Kneza Viseslava 3

11000 Belgrade

Serbia
\end{abstract}

aleksandar.lucic@gmail.com

\begin{abstract}
Vasilije Isajev
Faculty of Forestry Kneza Viseslava 1

11000 Belgrade

Serbia
\end{abstract}

Tatjana Ćirković-Mitrović

Institute of Forestry,

Kneza Viseslava 3

11000 Belgrade

Serbia

\author{
Ljubinko Rakonjac \\ Institute of Forestry, \\ Kneza Viseslava 3 \\ 11000 Belgrade \\ Serbia
}

Vladan Popović

Institute of Forestry,

Kneza Viseslava 3

11000 Belgrade

Serbia

\section{Ljiljana Brašanac-Bosanac}

Institute of Forestry,

Kneza Viseslava 3

11000 Belgrade

Serbia

\section{Abstract}

Background and purpose: The aim of present research is to study intra- and inter-population genetic variation in Austrian pine by the application of biochemical markers. A better knowledge of the genetic potential of Austrian pine populations will enhance the production of seed and planting material, and in this way also the success of afforestation and the establishment of Austrian pine specific-purpose plantations.

Material and methods. The polymorphism of protein markers was determined based on the selected genotypes originating from six populations (seed stands) in Serbia. Based on the derived electrophoregrams, qualitative and quantitative differences (number and pattern) in protein fractions were identified and the seed protein profile was constructed for each tree, as well as for each of the six study populations. Analysis of protein markers was performed using two statistical methods, NTSYS and correspondence analysis.

Results and conclusion: The conservativeness of some polypeptide, i.e. the presence in all analysed genotypes is showed. On the other hand, some protein fractions were variable at the population level, and some were variable depending on the population. The degree of genetic variation among the populations was higher than the variation within the populations. There was also a high genetic variation in seed proteins within the analysed populations. Both methods (NTSYS and correspondence analysis) give the same arrangement of the analyzed populations, whereby, because of a different view of genetic distances, they can and should be combined, enabling easier and more precise understanding of mutual relationships of the observation units.

Keywords: Austrian pine, proteins, polymorphism

\section{INTRODUCTION}

Pinus is considered as one of the most genetically variable plant genera, which is revealed by the assessment of its quantitative genetic variation [1], isozyme analysis [2-5] and RAPD markers [6-10].

For more than a century, Austrian pine has been in the focus of forestry scientific and professional public. 
The interest in this species is primarily the result of its characteristics: high genetic potential and genetic variation, as well as the taxonomic complexity and plasticity of the species. Its protective and reclamation function on the most severe terrains is the consequence of its extraordinarily low site demands. Austrian pine thriving over large areas attacked by erosion, or on completely degraded and denuded areas, where it produces excellent results, classifies it among the most important economic species in forestry. All the above Austrian pine characteristics, along with its wide native range and disjuct distribution, led to Austrian pine intensive introduction to the sites outside its native range, which resulted in a great number of subspecies and transition forms. The result of this natural variation is a high genetic potential which provides the base and the potential for the successful breeding of the species.

Taking into account the advancement of the concepts of nursery production, i.e. the tendency of abandoning the planting material production at the level of the species $[11,12]$ and in the aim of the most efficient and fast realisation of the tasks, it is necessary to enhance the study of the genetic potential of Austrian pine populations, because its directed implementation can improve the production of seed and planting material, and in this way also the success of afforestation and establishment of specific-purpose plantations of this species.

Consistent with the above problem which is assigned to modern forestry, the objective of the present study is to research and identify genetic variability of Austrian pine in Serbia, as one of the most important commercial species, irreplaceable in afforestation.

\section{MATERIAL AND METHOD}

The Official List of seed stands in Serbia includes six Austrian pine seed stands, which are presented in Figure 1 and Table 1.

Thanks to the occasional abundant yield of Austrian pine seed stands in Serbia, in October and November 2005, it was possible to collect the seeds at all six sites and in this way to embrace all Austrian pine seed stands.

The proteins were isolated from seeds of 55 trees of six populations, according to Wang et a. [14], and separated by PAGE according to Leammli [15]. The qualitative and quantitative differences (number and pattern) in protein fractions were detected based on the electrophoregrams. Coefficients of similarity were calculated after Jaccard [16] and Sokal and Michener [17].
TABLE 1

Main data on seed stands [13]

\begin{tabular}{|c|c|}
\hline & Population of Austrian pine \\
\hline I & MU "Divan-Breze", 27a.; \\
FE "Šumarstvo" Raška
\end{tabular}

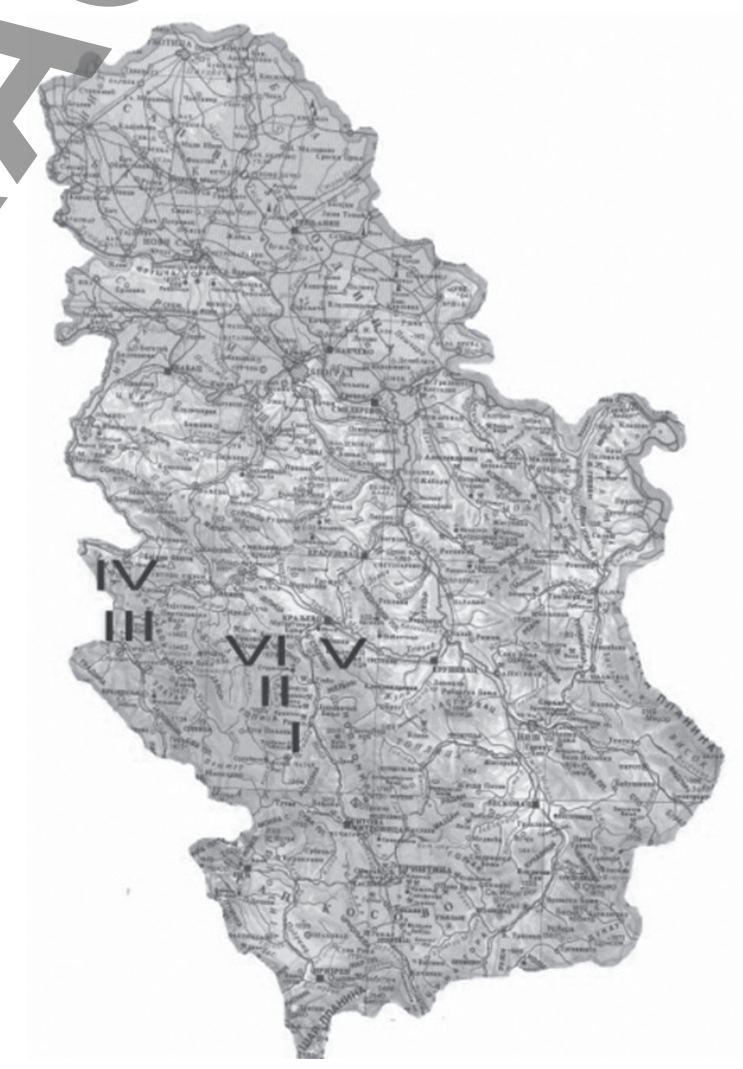

FIGURE 1

The studied populations of Austrian pine 
Jaccard

Sokal i Michener

$$
\begin{aligned}
\mathrm{GS}_{\mathrm{ij}} & =\mathrm{a} / \mathrm{a}+\mathrm{b}+\mathrm{c} ; \\
\mathrm{GS}_{\mathrm{ij}} & =\mathrm{a}+\mathrm{d} / \mathrm{a}+\mathrm{b}+\mathrm{c}+\mathrm{d}
\end{aligned}
$$

Where:

a - band presence in both genotype $i$ and $j(1.1)$

b - band presence in genotype $i$ and absence in genotype $j(1.0)$

c - band presence in genotype $j$ and absence in genotype and (0.1)

d - band absence in both genotype $i$ and genotype $j(0.0)$

Cluster analyses were carried out on the matrix of genetic similarities using the unweighted pair-group method using arithmetic averages (UPGMA) clustering algorithm. The dendrograms were constructed using NTSYS-PC software [18]. Also, a graphic interpretation of obtained results was made using graphics of correspondence analysis in 3D.

\section{RESULTS AND DISCUSSION}

The polymorphism of protein markers intra and inter Austrian pine populations was identified based on the selected genotypes within each population. The analysis of the derived electrophoregrams shows clearly that the analysed samples had a specific protein pattern. In order to determine the genetic similarity among the study genotypes, NTSYS dendrogram and graphs of correspondence analysis was performed based on the analysis of protein markers within Austrian pine populations.

The similarity matrices after Jaccard and Sokal and Michener produced diagram I with the identical pattern of genotypes within population I, and genotypes within population II, i.e. VI, whereas the values of genetic similarity were in different ranges. The graphical analysis of genotypes in population II distinguishes tree groups (Diagram 1). One group consists of genotypes II-1, II-7 and II-8, and the other is formed of genotypes II-2, II-4, II-3, II-5 and II-6. It should be noted that the grouping within groups occurs at small genetic distances. The line which consists of genotypes II-9 and II-10 is loosely linked to the above groups. Based on protein image, genotypes II-2 and II-4, as well as $\|-9$ and $\mu-10$, are genetically identical.

It is characteristic for the populations III, IV and $V$, that the similarity matrices after Jaccard and Sokal and Michener did not produce NTSYS dendrograms and graphics of correspondence analysis with the identical patterns of genotypes, and the values of genetic similarity were also in different ranges. The graphical analysis for population IV shows two groups and one loosely linked line, which consists
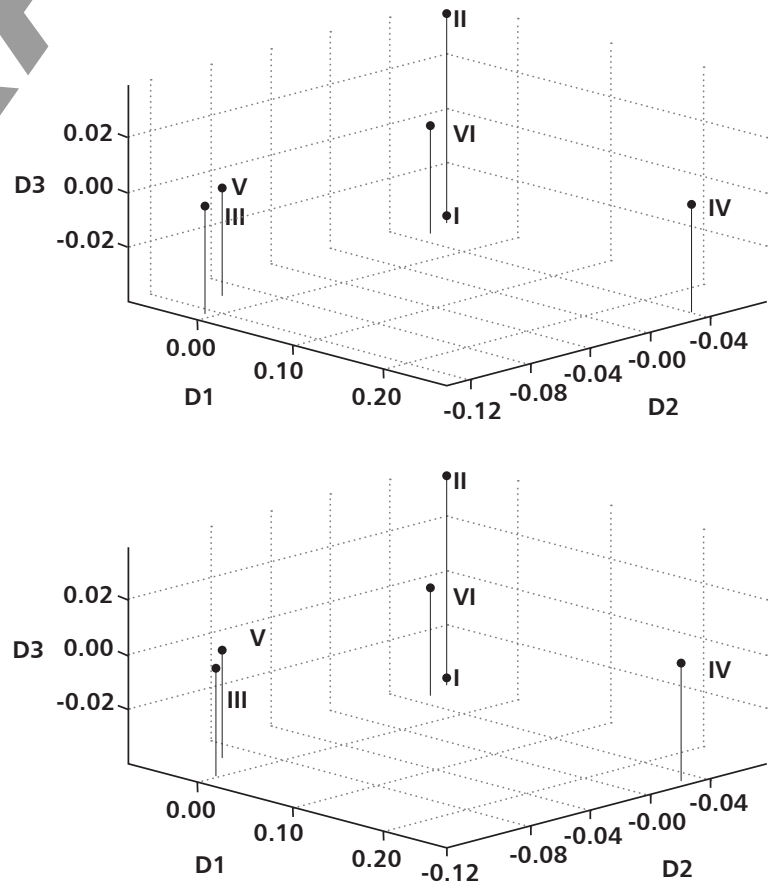
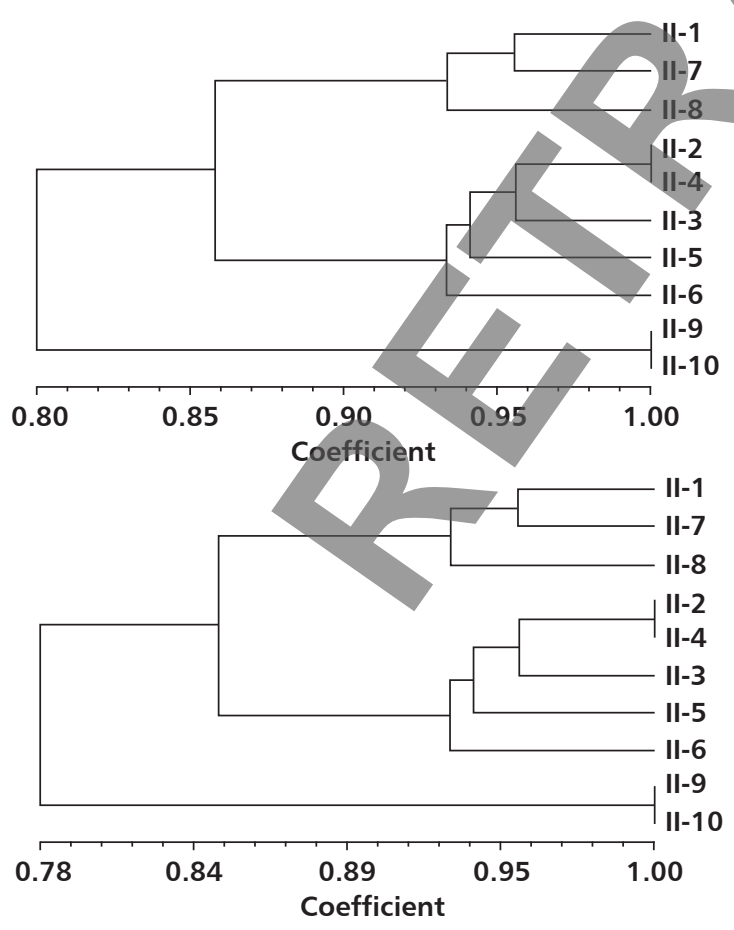

NTSYS dendrograms and graphics of correspondence analysis of population II genotypes after Sokal and Michener (a) and after Jaccard (b) 

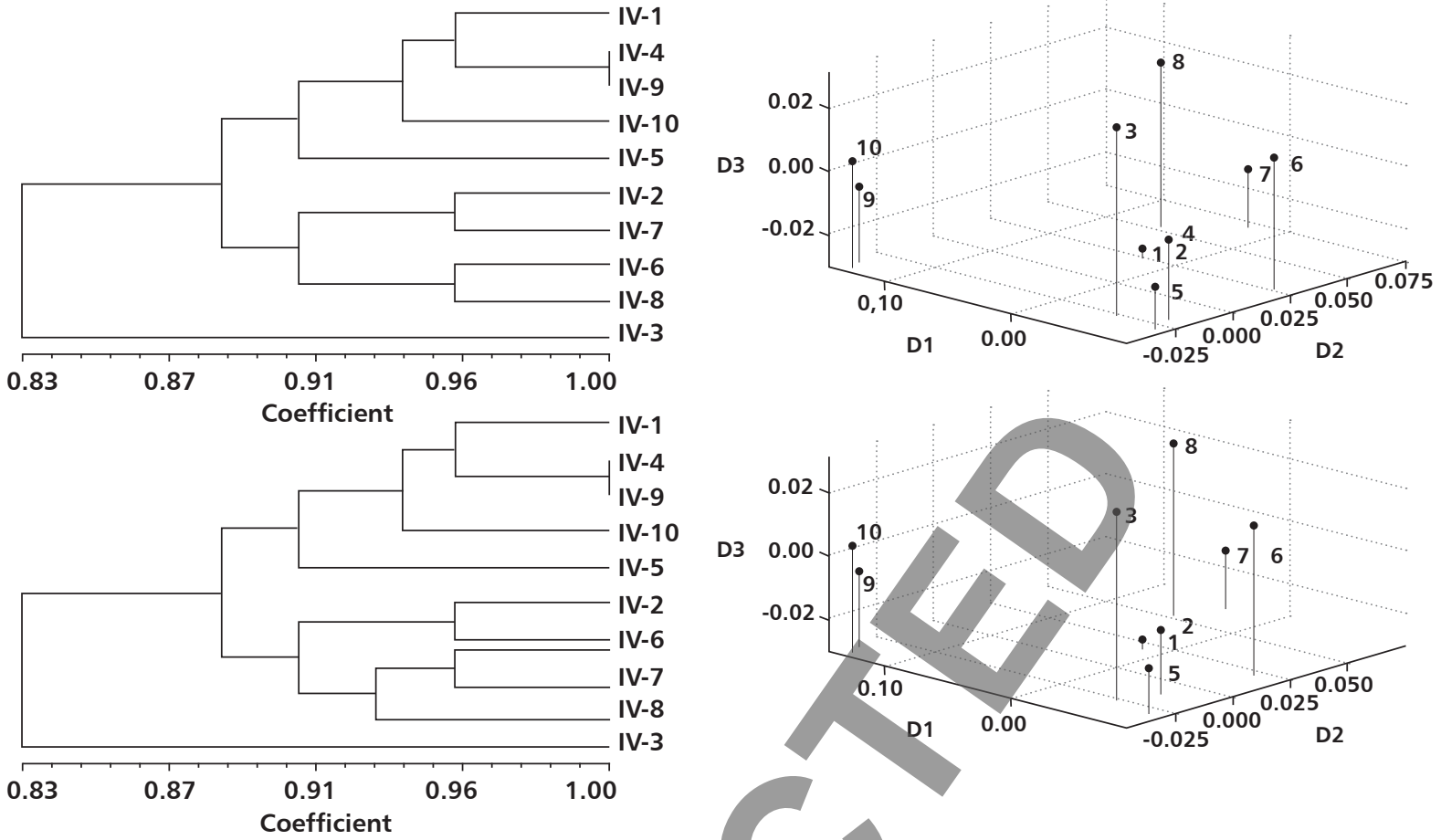

DIAGRAM 2

NTSYS dendrograms and graphics of correspondence analysis of population IV genotypes after Sokal and Michener (a) and after Jaccard (b)

of IV-3 genotype (Diagram 2). One group consists of types IV-4 and IV-9. Population V is characterised by genotypes IV-1, IV-4, IV-9, IV-10 and IV-5, while the the fact that it has a significantly different pattern other group consists of genotypes IV-2, IV-7, IV-6 of genotypes, depending on the applied method. and IV-8, which have different patterns depending The common characteristic of both methods is the on the applied method. Based on the analysis of pro- loose link of genotypes V-2 and V- 6 to other genotein markers, it is not possible to separate the genotypes (Diagram 3).
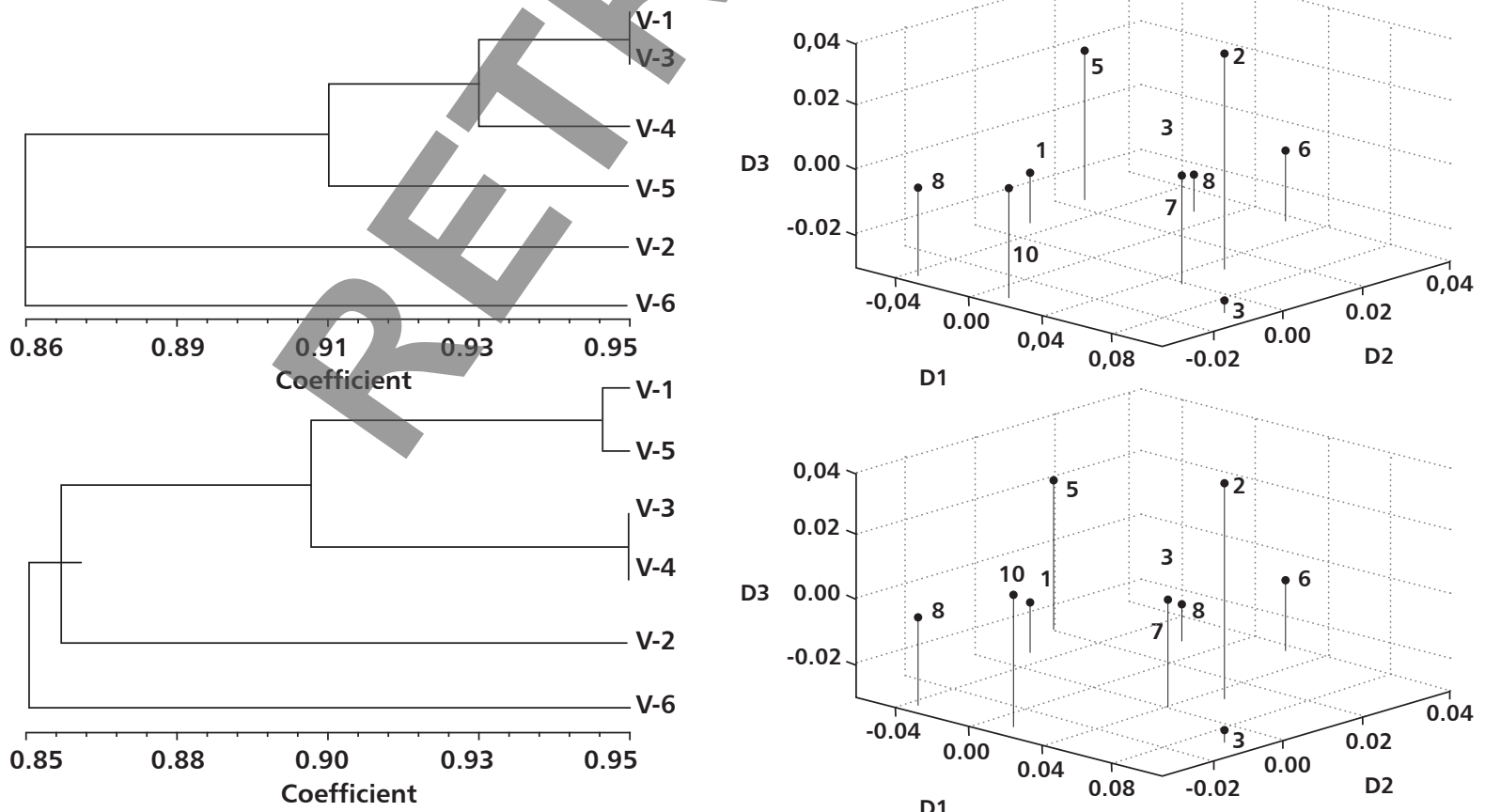

DIAGRAM 3

D1

NTSYS dendrograms and graphics of correspondence analysis of population $V$ after Sokal and Michener and after Jaccard 
The values of intrapopulation diversity of protein markers were different among the six Austrian pine populations under study. The similarity coefficients of seed proteins of the above populations showed a high variation, which ranged from 0.64 to 0.95 .

The analysis of polypeptide pattern, individual for each genotype, based on the cluster analysis dendrogram (Diagram 4) shows, with minor deviations, that the genotypes clustered in two groups, based on both similarity coefficients. The larger group consists of the genotypes in five populations (I, II, III, V and $\mathrm{VI}$ ) and the other group consists of the genotypes in population IV. The genotype pattern in groups and subgroups differs depending on the applied coefficient. Based on Jaccard coefficients, the genotypes in population III are grouped together, making one subgroup, which also includes genotype V-5. The

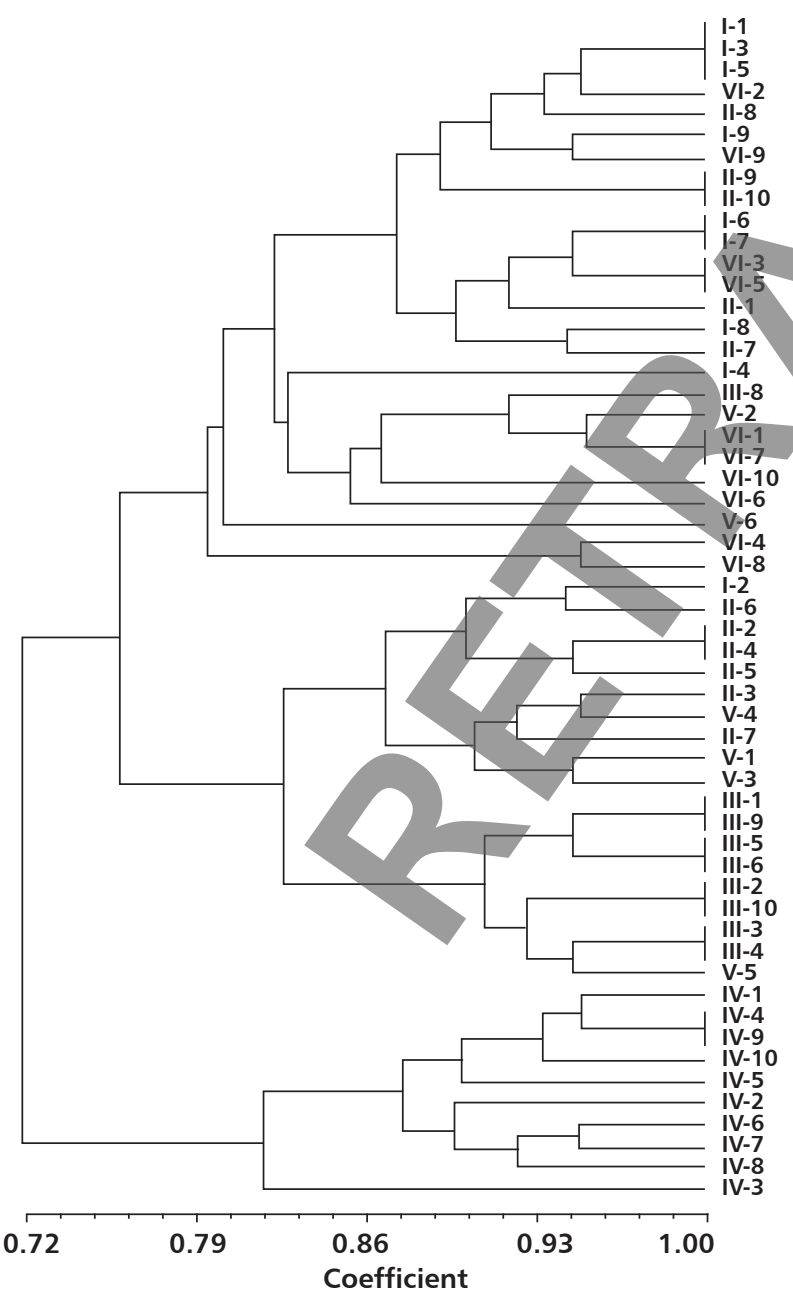

genotypes in population I, II and VI are grouped in smaller subgroups within group I, while the genotypes in population $V$ are grouped without any rule. Based on Sokal and Michener coefficients, genotypes in population IV form a special group. Within the first group, there are several differences in genotype patterns in subgroups according to Jaccard's dendrogram. Thus, genotype I-8, according to Sokal and Michener, is grouped together with another three genotypes in population I, whereas according to Jaccard, this genotype is grouped together with genotype II-7. Three genotypes in population $\mathrm{V}$ are also grouped together with the genotypes in population III. Based on the above dendrograms, at the population level, the genotypes are grouped within individual populations. This confirms the minor differences in site conditions and the differences among genotypes, and emphasises the significance of the populations. 
Graphics of correspondence analysis are not shown because the large number of genotypes led to inability to analyze the obtained results.

The results of the analysis of protein complex show that seed samples from different populations had different protein pattern. Two seeds were taken from each of 55 trees in six populations and grouped by localities, after which seed proteins were isolated from the formed sample and analysed by electrophoresis. The differences in number, pattern of protein fractions were determined. Total number of protein fractions was 22 , of which 11 were polymorphic (50\%). Seed protein profile was established based on the electrophoregram for each of the six study populations and the genetic similarity coefficients among the study populations were calculated.

To determine the genetic similarity among the study genotypes, NTSYS dendrograms and graphics of correspondence analysis was performed based on the analysis of protein markers among Austrian pine populations.

Similarity matrices after Jaccard and Sokal and Michener generated the dendrograms with the identical pattern of genotypes, while the values of genetic similarity were in different ranges. Same results were obtained using graphics of correspondence analysis.

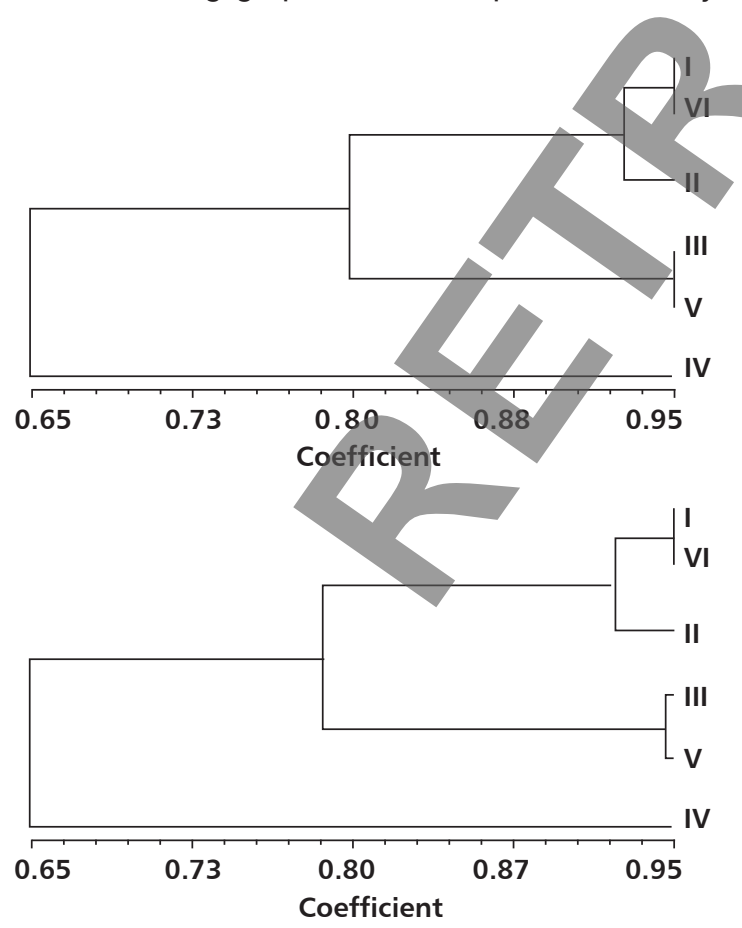

NTSYS dendrograms and graphics of correspondence analysis of the populations were characterised by a high genetic diversity among the study populations expressed by the graphical form. The comparative analysis of the generated NTSYS dendrograms and graphics of correspondence analysis shows clearly that, populations I and VI, as well as III and V, were at the smallest genetic distances. Population II was more loosely linked to populations I and VI than to III and V. An interesting characteristic of NTSYS dendrograms and graphics of correspondence analysis is the character of the link of population IV to other populations. Austrian pine on Mt. Šargan had an extremely loose link to other populations, which was the result of a great genetic distance compared to other populations. Similarity matrices according to Jaccard and Sokal and Michener were compared by Mantel test. A high degree of correlation was established between pairs of similarity matrices $(r=0.997)$.

Seed proteins are relatively frequently applied as genetic markers in the study of forest tree genomes, but there are relatively few studies on Austrian pine [5, 19]. The polymorphism of Austrian pine seed proteins was researched aiming at the assessment of genetic variation intra- and inter- populations. There was a higher degree of genetic variation among populations than within populations. Also there was a high genetic variation of seed proteins within populations.
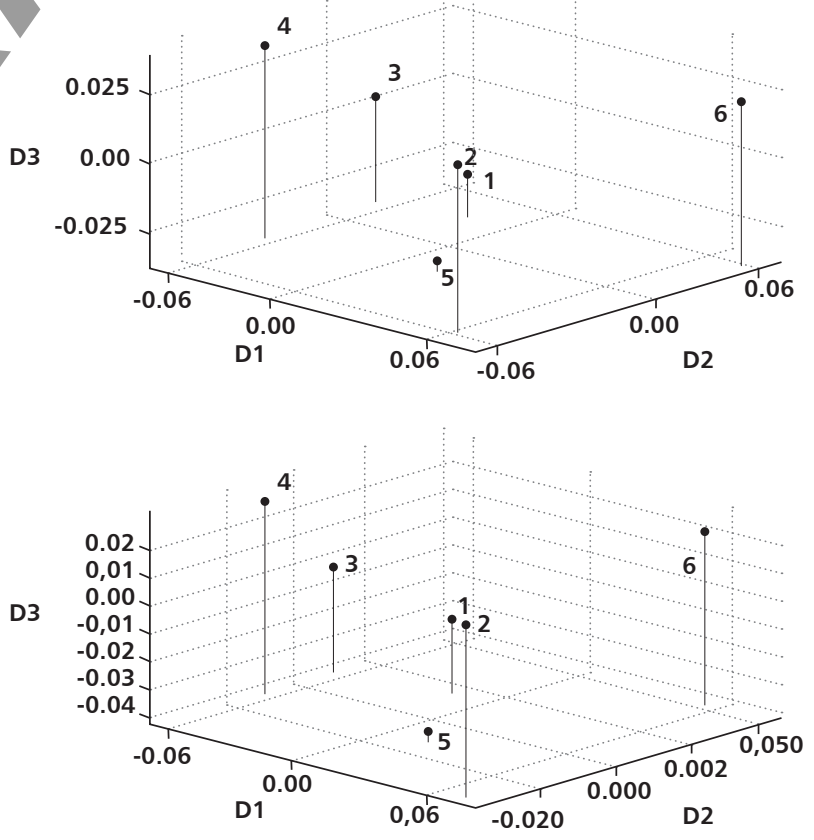
These results are compatible with the results reported by Forrest [20] and Mataruga [5], which point to the absence of site effects on the protein complex, as well as with the results which show the variation among the analysed populations which are spatially isolated, Bahrman [21]. In general, conifers are characterised by a very high level of genetic variation, Hamrick [2], and the potential factors are a) longevity, free pollination with high fertility, and b) divergent selection for macro-micro geographic adaptation. According to Scaltsoyiannes et al. [22], Pinus nigra is characterised by a high total variation because of the high intrapopulation genetic variation, which points to a high genetic variation in local populations and the possibility that the same alleles are distributed throughout the entire range of this species.

\section{CONCLUSIONS}

Based on the study results, it can be concluded that the analysis of seed proteins shows a specific protein pattern of all analysed genotypes. This showed the "conservativeness" of some polypeptides, i.e. the presence in all analysed genotypes. On the other hand, some protein fractions were variable at the population level, and some were variable depending on the population.

Based on the cluster analysis, the population IV, MU "Šargan" 22b, FE "Užice" - Užice was clearly separated from other populations, and populations III and $\mathrm{V}$ were grouped together at smaller distances. Popula-

\section{REFERENCES}

1. CORNELIUS J 1994 Heritabilities and additive genetic coefficients of variation in forest trees. Can J Forest Res (24): 372-379

2. HAMRICH J L, LINHART Y B, MITTON J B 1979 Relationships between life history characteristics and electrophoretically detectable genetic variation in plants. Annu Rev Ecol Syst (10): $173-200$

3. HAMRICH J L, GODT M J W 1990 Allozyme diversity in plants species. Plant population genetics, breeding and genetic resources. Sinauer associates inc. Sunderland, Massachusetts, pp 43-63

4. LEWANDOWSKI A, SAMOCKO J, BORATYNSKA K, BORATYNSKA A 2002 Genetic differences between two Polish populations of Pinus uliginosa, compared to P. sylvestris and P. mugo. Dendrobiology 48: 51-57

5. MATARUGA M 2006 Austrian pine (Pinus nigra Arn.) growing on the rocks - its variability and various possibilities of its use. Faculty of Forestry, University of Banja Luka. Banja Luka

6. LEE S W, LEDIG F T, JOHNSON D R 2002 Genetic variation at allozyme and RAPD markers in Pinus longaeva (Pinaceae) tion IV had the smallest genetic similarity among the analysed genotypes, showing the greatest distance from populations I, II and V, and a slightly greater genetic similarity with populations III and VI.

The values of intrapopulation diversity in the applied markers are much higher than it was recorded among the study of six Austrian pine seed stands. From the aspect of commercial forest seed production, the results are significant for future activities on defining Austrian pine population regions in Serbia, because they point to the fact that the genetic distances among the analysed seed stands are such that they can affect the future trade of seed material in the sense of its use in specific-purpose nursery production.

Both methods (NTSYS and correspondence analysis) give the same arrangement of the analyzed populations, whereby, because of a different view of genetic distances, they can and should be combined, enabling easier and more precise understanding of mutual relationships of the observation units.

\section{Acknowledgements}

The research is financed by the Ministry of Education, Science and Technological Development of the Republic of Serbia, Project TR 31070 "The development of technological procedures in forestry with a view to an optimum forest cover realisation" (20112014).

of the White Mountains, California. Am J Bot 89: 566-577

7. NKONGOLO K K, MICHAEL P, GRATTON W S 2002 Identification and characterization of RAPD markers inferring genetic relationships among Pine species. Genome 45 (1): $51-58$

8. MONTELEONE I, FERRAZZINI D, BELLETTI P 2006 Effectiveness of neutral RAPD markers to detect genetic divergence between the subspecies uncinata and mugo of Pinus mugo Turra. Silva Fenn 40: 391-406

9. LUČIĆ A, MLADENOVIĆ-DRINIĆ S, STAVRETOVIĆ N, ISAJEV V, LAVADINOVIĆ V, RAKONJAC U, NOVAKOVIĆ M $2010 \mathrm{Ge}$ netic diversity of Austrian pine (Pinus nigra Arnold) populations in Serbia revealed by RAPD. Arch Biol Sci Belgrade 62 (2): 329-336

10. LUČIĆ A, ISAJEV V, RAKONJAC L, RISTIĆ D, KOSTADINOVIĆ M, BABOĆ V, NIKOLIĆ A 2011 Genetic Divergence of Scots Pine (Pinus sylvestris L.) Populations in Serbia Revealed by Rapd. Arch Biol Sci Belgrade 63 (2): 371-380

11. ISAJEV V, TUCOVIĆ A, MATARUGA M 1998 Improving of reforestation technology of degraded habitats. Counseling: Some issues related to forests and water and possible solutions. State Enterprise for Forest Management "Srbijašume" Belgrade 
12. MATARUGA M, ISAJEV V 1998 Possibilities of testing and conservation of Austrian pine (Pinus nigra Arn.) biodiversity in specialized plantations. Protection of Nature 50: 6369

13. Official List of seed stands of Republic of Serbia 105/2005

14. WANG C, BIAN K, ZHANG H, ZHOU Z, WANG J 1994 Polyacrylamide gel electrophoresis of salt soluble proteins for maize variety identification and genetic purity assessment. Seed Sci Tech 21: 51-57

15. LAEMLLI V K 1970 Cleavage of structural proteins during the assembly of the head of bacteriophage T4. Nature 227: 680-685

16. JACCARD P 1908 Nouvelles rescherches sur la distribution floral. Bull Soc Vand Sci Nat 44: 223-270

17. SOKAL R R, MICHENER C D 1958 A statistical method for evaluating systematic relationships. Univ Kans Sci Bull 38: 1409-1438

18. ROHLF F J 2000 NTSYS-pc. Numerical taxonomy and multivariate analysis system. Version 2.0 Exeter Software, Setaket, N.Y.

19. ISAJEV V, RADOTIĆ K 2007 Variability of peroxidase activity and heavy metal content in the needles of Austrian pine
(Pinus nigra Arnold) half-sib lines. Genetics 39 (2): 241250

20. FORREST I G 1994 Biochemical Markers in Tree Improvement Programmes. Forestry Abstracts 55 (2): 123-150

21. BAHRMAN N, PETIT R J 1995 Genetic polymorphism in maritime pine (Pinus pinaster Ait.) assessed by two-dimensional gel electrophoresis of needle, bud and pollen proteins. J Mol Evol 41: 231-237

22. SCALTSOYIANNES A, ROHR R, PANETSOS K 1994 Allozyme frequency distribution in five european populations of black pine (Pinus nigra Arnold), Silvae Genet 43 (1): 20-25

23. MANTEL N 1967 The detection of disease clustering and a generalized regression approach. Cancer Res 27: 209-220

24. MATARUGA M, ISAJEV V, OCOKOLIĆ M, ŠIJAČIĆ-NIKOLIĆ M 1997 Analysis of Austrian pine development based on gene-ecological research. The $3^{\text {rd }}$ International conference on the development of forestry and wood science/technology. Proceedings book Vol. I, Belgrade, pp 51-59

25. TUCOVIĆ A, ISAJEV V 1990 Breeding of seeds and seedlings and reforestation. Counseling: Modern methods of reforestation, care and protection in conservation and expansion of the forest fund of Serbia. Proceedings book, Arandjelovac, pp 72-81 